\title{
TROPHIC INFERENCE IN TWO SYMPATRIC SHARKS, SPHYRNA LEWINI AND CARCHARHINUS FALCIFORMIS (ELASMOBRANCHII: CARCHARHINIFORMES), BASED ON STABLE ISOTOPE ANALYSIS AT MALPELO ISLAND, COLOMBIA
}

\author{
Colombo ESTUPIÑÁN-MONTAÑO ${ }^{1 *}$, Felipe GALVÁN-MAGAÑA², Elena TAMBURÍN ${ }^{1}$, \\ Alberto SÁNCHEZ-GONZÁLEZ², Daniel J. VILLALOBOS-RAMÍREZ ${ }^{3}$, \\ Nancy MURILLO-BOHÓRQUEZ ${ }^{3}$, Sandra BESSUDO-LION ${ }^{4}$, and José F. ESTUPIÑÁN-ORTIZ ${ }^{1}$ \\ ${ }^{1}$ Fundación Alium Pacific, Santiago de Cali, Colombia \\ ${ }^{2}$ Centro Interdisciplinario de Ciencias Marinas, Instituto Politécnico Nacional, La Paz, BSC, Mexico \\ ${ }^{3}$ Parques Nacionales Naturales de Colombia, Bogotá, Colombia \\ ${ }^{4}$ Fundación Malpelo y Otros Ecosistemas Marinos, Bogotá, Colombia
}

\begin{abstract}
Estupiñán-Montaño C., Galván-Magaña F., Tamburin E., Sánchez-González A., Villalobos-Ramírez D.J., Murillo-Bohórquez N., Bessudo-Lion S., Estupiñán-Ortiz J.F. 2017. Trophic inference in two sympatric sharks, Sphyrna lewini and Carcharhinus falciformis (Elasmobranchii: Carcharhiniformes), based on stable isotope analysis at Malpelo Island, Colombia. Acta Ichthyol. Piscat. 47 (4): 357-364.
\end{abstract}

Background. Elasmobranchs can play important roles in marine communities. But, relatively little is known about their diet, and movement. Sphyrna lewini (Griffith et Smith, 1834) consumes fishes, cephalopods, rays, and crustaceans. Carcharhinus falciformis (Müller et Henle, 1839) feed on fishes, cephalopods, crustaceans and sea turtles. To date, there are no studies available on the trophic ecology of sharks in Malpelo Island. The aim of this study was to describe the trophic ecology of $S$. lewini and C. falciformis, using stable isotope analysis of $\delta^{13} \mathrm{C}$ and $\delta^{15} \mathrm{~N}$, to better understand the role of both shark species in the Malpelo Island ecosystem.

Material and methods. In January, February, and November 2013, specimens of Sphyrna lewini and Carcharhinus falciformis illegally caught at Malpelo Island were confiscated at the port of Buenaventura, Colombia. For each shark specimen, total length and sex were registered. Samples of muscle tissue were taken from the nape of all specimens. Each muscle sample was lyophilized for $24 \mathrm{~h}$ and analysed with lipid and urea extraction and without extraction. For each shark specimen, a subsample of $\sim 1.0 \mathrm{mg}$ was used for isotopic analysis.

Results. A total of 14 Sphyrna lewini (Griffith et Smith, 1834) and 12 Carcharhinus falciformis (Müller et Henle, $1839)$ were analysed. $\delta^{13} \mathrm{C}$ values were similar between $S$. lewini $(-16.3 \pm 0.1 \%$ ) and $C$. falciformis $(-16.5 \pm 0.1 \%)$. Sphyrna lewini showed a wider trophic niche than C. falciformis, with low trophic overlap $(5 \%)$ between the two species. The $\delta^{15} \mathrm{~N}$ values of $S$. lewini $(15.9 \pm 0.11 \%$ ) were higher than those of $C$. falciformis $(14.9 \pm 0.09 \%$ ). In $C$. falciformis, $\delta^{13} \mathrm{C}$ values were similar in both sexes $\left(-16.5 \pm 0.1 \%\right.$ ), while $\delta^{15} \mathrm{~N}$ values were significantly different between males $(14.6 \pm 0.1 \%$ ) and females $(15.0 \pm 0.1 \%$ ). The trophic position of $S$. lewini was $5.25 \pm 0.12$, and that of $C$. falciformis, $5.48 \pm 0.18$, which suggests that both shark species occupy a high position in the marine food chain. Conclusion. Both shark species co-occur at Malpelo Island, but they do not share food resources and feeding areas, and they probably feed far from the island, using it as a resting and cleaning area. This indicates the need for more research to increase biological and ecological knowledge of both species, particularly within marine protected areas and their influence areas throughout the Colombian Pacific.

Keywords: Trophic ecology, carbon isotopes, nitrogen isotopes, resource partitioning, trophic level

\section{INTRODUCTION}

Elasmobranchs can play important roles in marine communities, occupying a wide range of habitats as apex predators. However, relatively little is known about their abundance, diet, and movement (Baum et al. 2003, 2005, Heithaus et al. 2008, Hussey et al. 2012). Many shark species are in decline, mainly due to overfishing, bycatch, pollution, and habitat degradation (Baum et al. 2003, 2005, Dulvy et al. 2008).

Knowledge of diet, trophic position, movement patterns and habitat use of species have been recognized as critical factors in implementing successful conservation 
and management strategies of species and the environment (Hussey et al. 2012). The diets and trophic interactions of elasmobranchs are sometimes difficult to determine using traditional methods alone (e.g., gut content analysis, direct observations, tagging), however, a complementary technique is stable isotope analysis (SIA). SIA is an important, effective tool that can be applied to elasmobranch conservation research (Kim et al. 2012, Shiffman et al. 2012). This technique is based on the premise that heavy isotopes of an element are preferentially retained (e.g., nitrogen isotopes via protein amination/deamination, carbon isotopes via respiration) and that specific ratios of heavy to light isotopes are indicative of specific resource use (e.g., diet and habitat) (Wolf et al. 2009) and trophic position (Post 2002). This biogeochemical method allows quantitative analysis of dietary composition and foraging patterns over a range of spatial and temporal scales (MacNeil et al. 2005), as well as the examination of more complex questions pertaining to community dynamics, feeding strategies or diet, trophic position, and movement in aquatic organisms (Hussey et al. 2012).

The scalloped hammerhead shark, Sphyrna lewini (Griffith et Smith, 1834), and silky shark, Carcharhinus falciformis (Müller et Henle, 1839), have a circumtropical distribution and occur in the Eastern Tropical Pacific (ETP) from southern California (USA) to Peru (Compagno 1984, Fischer et al. 1995, Robertson and Allen 2002). The species $S$. lewini and C. falciformis are listed as "Endangered" (Baum et al. 2007) and "Near Threatened" (Rigby et al. 2017), respectively, in the International Union for Conservation of Nature (IUCN) Red List.

Sphyrna lewini inhabits coastal and oceanic zones in tropical and subtropical seas of the world (Compagno 1984). In the ETP, S. lewini often forms schools around oceanic islands and seamounts (Klimley 1981, Klimley and Nelson 1981), particularly in marine protected areas, and makes vertical movements and horizontal migratory movements between Malpelo Island (Colombia), Cocos Island (Costa Rica), and the Galapagos Islands (Ecuador) (Bessudo et al. 2011a, 2011b). In the ETP, S. lewini consumes a wide variety of prey species, from benthic, neritic, and epipelagic fishes to cephalopods, rays, lobsters, shrimps, and crabs (TorresRojas et al. 2006, Estupiñán-Montaño et al. 2009, TorresRojas et al. 2010, Zanella et al. 2010, Galván-Magaña et al. 2013, Torres-Rojas et al. 2015).

The silky shark, Carcharhinus falciformis, is a tropical species abundant in oceanic and epipelagic areas (Compagno 1984). Carcharhinus falciformis feeds on a large number of prey species, from pelagic and coastal fishes (e.g., tunas, mullets, mackerel) to cephalopods, crustaceans, and sea turtles (Cabrera-Chávez-Costa et al. 2010, Duffy et al. 2015, Estupiñán-Montaño et al. 2017). This shark is considered a piscivorous predator, consuming mainly fishes of the Scombridae family (Duffy et al. 2015, Estupiñán-Montaño et al. 2017).

This is the first study of the trophic ecology of the sharks, Sphyrna lewini and Carcharhinus falciformis, in an area of sympatry, Malpelo Island. Malpelo Island is a marine reserve located $\sim 490 \mathrm{~km}$ off the coast of
Buenaventura, Colombia (Fig. 1). The species under study are the most abundant sharks at Malpelo Island. Thus, the aim of this study was to describe the trophic ecology of these two shark species, using stable isotope analysis of carbon $\left(\delta^{13} \mathrm{C}\right)$ and nitrogen $\left(\delta^{15} \mathrm{~N}\right)$, to better understand the role of both shark species in the Malpelo Island ecosystem.

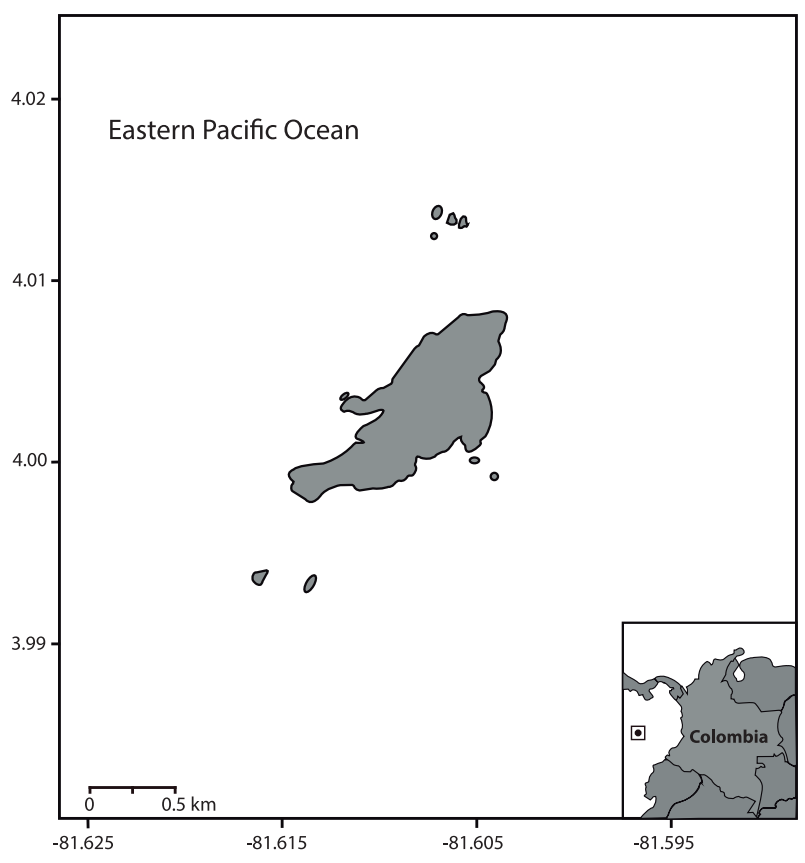

Fig. 1. Geographic location of Malpelo Island, Colombia

\section{MATERIAL AND METHODS}

In January, February, and November 2013, a total of 14 Sphyrna lewini and 12 Carcharhinus falciformis illegally caught at Malpelo Island were confiscated at the port of Buenaventura, Colombia. For each shark specimen, total length (TL, in cm) was measured and sex was determined. Samples of muscle tissue were taken from the nape of all specimens, stored in plastic bags, and frozen for transport to the laboratory.

Each muscle sample was lyophilized for $24 \mathrm{~h}$ and analysed with lipid and urea extraction (lipid-free) and without extraction (Bulk). Lipid and urea extraction was performed following the procedure described by Kim and Koch (2012). After drying, each sample was homogenized using an agate mortar to produce a very fine powder. For each shark specimen, a subsample of $0.3-1.0 \mathrm{mg}$ of powder was obtained and loaded into a tin capsule for isotopic analysis. To know if lipid extraction was necessary, the $\mathrm{C} \div$ $\mathrm{N}$ ratios of both sets of samples (Free-lipid and Bulk) were measured. $\mathrm{A} \mathrm{C} \div \mathrm{N}$ mass ratio $<3.5$ indicated there was no effect of lipid content (Post et al. 2007).

Isotope ratios were measured using a Thermo Scientific $^{\mathrm{TM}}$ Delta V Plus $^{\mathrm{TM}}$ isotope-ratio mass spectrometer (IRMS), with ConFlo IV interface and a Costech $^{\mathrm{TM}}$ elemental analyser, in the chemistry laboratory of the Centro Interdisciplinario de Ciencias Marinas, Instituto Politécnico Nacional (CICIMAR-IPN) in La Paz, Mexico. Isotope ratios are presented using $\delta$ notation: 


$$
\delta^{h} X=\left(\frac{R_{\text {sample }}}{R_{\text {standard }}}-1\right) \times 1000
$$

where $X$ is the element, $h$ is the high mass number, $R_{\text {sample }}$ is the heavy-to-light isotope ratio, and $R_{\text {standard }}$ is Vienna Pee Dee Belemnite for carbon and AIR for nitrogen. Units are parts per thousand (\%). The precision of the method was $\pm 0.3 \%$ and $\pm 0.1 \%$ for $\mathrm{C}$ and $\mathrm{N}$ stable isotopes, respectively.

The trophic position (TP) was calculated using the equation proposed by Post (2002):

$$
T P=\lambda+\left(\frac{\delta^{15} \mathrm{~N}_{\text {predator }}-\delta^{15} \mathrm{~N}_{\text {base }}}{\Delta_{n}}\right)
$$

where $\lambda$ is the TP of the base (i.e., the most important prey species for each predator); $\delta^{15} \mathrm{~N}_{\text {predator }}$ and $\delta^{15} \mathrm{~N}_{\text {base }}$ are the isotopic signatures of the predator and the base, respectively; and $\Delta_{n}$ is the trophic discrimination factor (TDF), $3.7 \pm 0.4 \%$ (Kim et al. 2012). The bases used for TP estimates were chosen from stomach contents studies (Estupiñán-Montaño et al. 2009, 2017) and the mixing model (Parnell et al. 2013). For Sphyrna lewini, the base comprised the squids Dosidicus gigas $(\lambda=4.14)$ (Pauly and Zeller 2015), $\delta^{15} \mathrm{~N}=10.1 \pm 1.3 \%$ (Bolaños unpublished*), Ommastrephes bartramii $(\lambda=4.20)$ (Pauly and Zeller 2015), $\delta^{15} \mathrm{~N}=10.0 \pm 0.4 \%$ ), and Lolliguncula (Loliolopsis) diomedeae $(\lambda=3.90)$ (Pauly and Zeller $2015), \delta^{15} \mathrm{~N}=12.5 \pm 0.2 \%$ (Bolaños unpublished ${ }^{*}$ ), and the fish Larimus argenteus $(\lambda=3.10)$ (Pauly and Zeller 2015 ), $\delta^{15} \mathrm{~N}=12.6 \pm 0.7 \%$ (Bolaños unpublished*, CalleMoran unpublished**). For Carcharhinus falciformis, the base comprised D. gigas, O. bartramii, and Sthenoteuthis oualaniensis $(\lambda=4.09)$ (Pauly and Zeller 2015), $\delta^{15} \mathrm{~N}=$ $10.4 \pm 0.18 \%$ (Calle-Moran unpublished) Auxis thazard $(\lambda=4.37)$ (Pauly and Zeller 2015), $\delta^{15} \mathrm{~N}=10.4 \pm 0.9 \%$ (Bolaños unpublished*, Calle-Mora unpublished ${ }^{* *}$ ), Anchoa spp. $(\lambda=3.46)$ (Pauly and Zeller 2015), $\delta^{15} \mathrm{~N}=$ $10.9 \pm 0.6 \%$ (Páez-Rosas et al. 2012) (Fig. 2).

Isotopic niche breadth and trophic overlap between species and sexes were estimated using SIBER (Stable Isotope Bayesian Ellipses in R) (Jackson et al. 2011) from the SIAR package (Stable Isotope Analysis in R) (Parnell and Jackson 2013). This analysis uses measurements based on ellipses calculated by a covariance matrix that defines their shape and area (Jackson et al. 2011) to show the trophic niche breadth (standard ellipse corrected area, SEA $)$. With this method it is possible to obtain the overlap between ellipses, where values close to 1 represent high trophic overlap (Jackson et al. 2011).

The normality and homoscedasticity of isotope data were tested using the Shapiro-Wilk and Levene's test, respectively. The parametric Student's $t$-test and the nonparametric Wilcoxon signed-rank test were used to

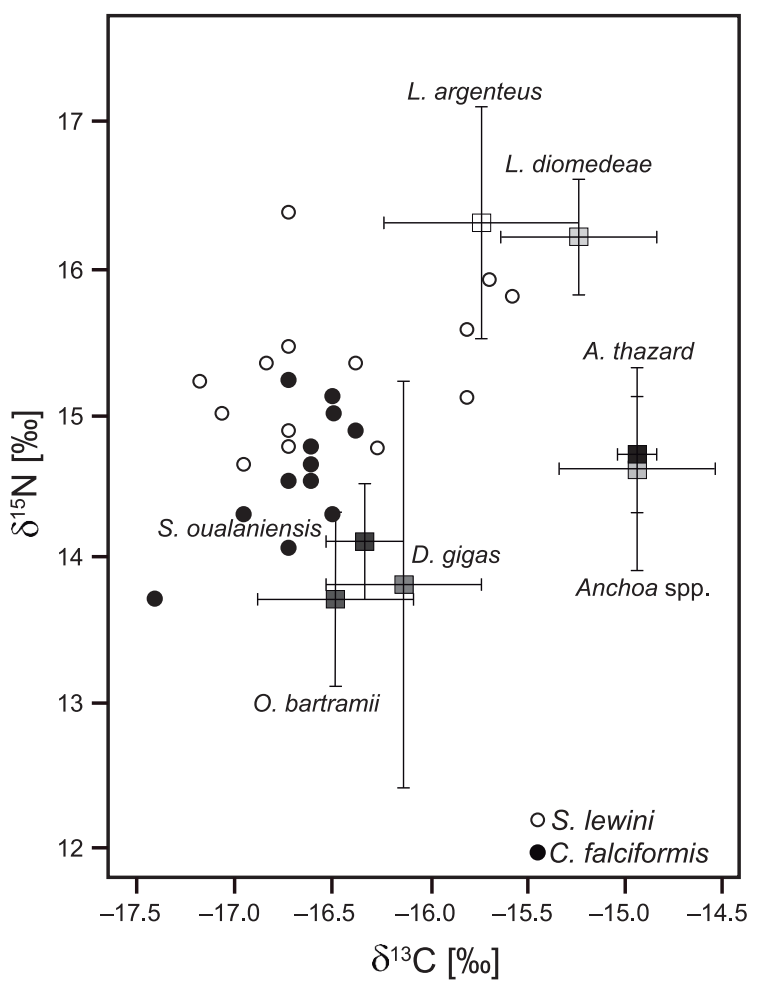

Fig. 2. Mixing model for Sphyrna lewini and Carcharhinus falciformis at Malpelo Island, Colombia

determine statistical differences in $\mathrm{C} \div \mathrm{N}$ ratio among shark species and sexes. All tests were performed using a significance level $(\alpha)$ of 0.05 . Statistical analyses and figures were obtained using the $\mathrm{R}$ statistical package ( $\mathrm{R}$ Core Team 2014).

\section{RESULTS}

The lengths of Sphyrna lewini ranged from 151.1 to $195.2 \mathrm{~cm} \mathrm{TL}$ (mean $\pm \mathrm{SE}: 135.25 \pm 19.9 \mathrm{~cm} \mathrm{TL}$ ). Carcharhinus falciformis lengths ranged between 112.4 and $245.7 \mathrm{~cm}$ TL (mean \pm SE: $147.96 \pm 10.6 \mathrm{~cm} \mathrm{TL}$ ).

For Sphyrna lewini, the $\mathrm{C} \div \mathrm{N}$ ratios of the bulk and lipid-free samples ranged from 2.71 to 3.19 and from 2.99 to 3.19, respectively. For Carcharhinus falciformis, the $\mathrm{C} \div \mathrm{N}$ ratio ranged from 2.81 to 3.10 (bulk samples) and from 2.81 to 3.07 (lipid-free samples). We found significant statistical differences in $\mathrm{C} \div \mathrm{N}$ ratio between bulk and lipid-free samples (Table 1), likely an effect of the lipid extraction process (Hussey et al. 2012). However, since $\mathrm{C} \div \mathrm{N}$ values were lower than 3.5 (Post et al. 2007), all the analyses were performed using the $\delta^{13} \mathrm{C}$ and $\delta^{15} \mathrm{~N}$ values of bulk samples.

No statistical difference was observed in $\delta^{13} \mathrm{C}$ values between Sphyrna lewini and Carcharhinus falciformis (Wilcoxon signed-rank test, $W=77, P=0.74$ ). However, Student's $t$-test showed a significant difference in $\delta^{15} \mathrm{~N}$ values between the two species $(t=-3.85$, d.f. $=23.99$, $95 \%$ IC $=-0.93$ to $-0.28, P=0.001$; Table 1 , Fig. 3 ).

\footnotetext{
* Bolaños N. 2009. Ecología trófica de juveniles de tiburón martillo Sphyrna zygaena (Linnaeus, 1758) en aguas ecuatorianas. Master thesis. Centro Interdisciplinario de Ciencias Marinas, La Paz, México.

${ }^{* *}$ Calle-Moran M. 2010. Ecología trófica del tiburón zorro pelágico Alopias pelagicus en Santa Rosa de Salinas, Pacífico ecuatoriano. Master thesis. Universidad Nacional Autónoma de México, México DF, México.
} 
In Sphyrna lewini, it was not possible to carry out the analysis between sexes because the sharks sampled were landed without fins (dorsal, pectoral, and pelvic). For Carcharhinus falciformis, comparisons between sexes indicated no statistical difference in $\delta^{13} \mathrm{C}$ values (Wilcoxon signed-rank test, $W=12.5, P=0.464)$, however, there was a significant difference in $\delta^{15} \mathrm{~N}$ values, with females being enriched in $\delta^{15} \mathrm{~N}$ (Wilcoxon signed-rank test, $W=0, P=$ 0.005; Table 2, Fig. 4).

The TP estimated for Sphyrna lewini was in the range of 3.83-5.94, and that of Carcharhinus falciformis was in the range of 5.10-5.81. For $C$. falciformis, the estimated $\mathrm{TP}$ was between 5.36 and $5.65($ mean $\pm \mathrm{SE}=5.51 \pm 0.03)$ for males, and between 5.31 and $5.81(5.63 \pm 0.04)$ for females. The relative TP of S. lewini and C. falciformis suggests that both species occupy a high position in the marine food chain (Table 3).

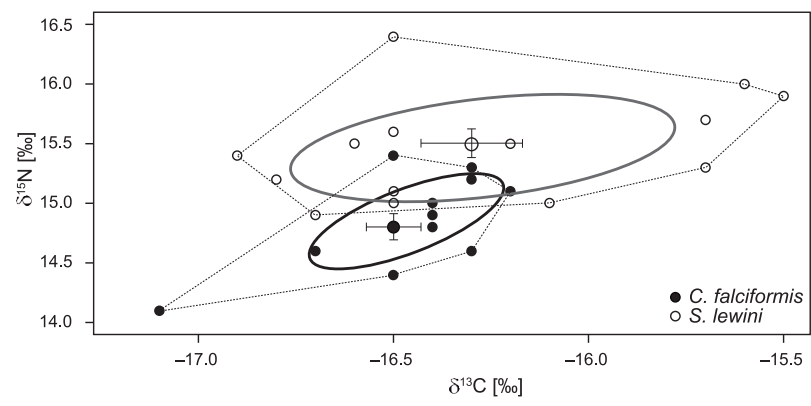

Fig. 3. Isotopic values of $\delta^{13} \mathrm{C}$ and $\delta^{15} \mathrm{~N}$ (mean $\pm \mathrm{SE}$ ) in Sphyrna lewini and Carcharhinus falciformis at Malpelo Island, Colombia
There was little isotopic overlap between Sphyrna lewini and Carcharhinus falciformis (5\%; Fig. 3), and the isotopic niche of $C$. falciformis $\left(\mathrm{SEA}_{\mathrm{c}}=0.20, n=12\right)$ was narrower than that of $S$. lewini $\left(\mathrm{SEA}_{\mathrm{c}}=0.64, n=14\right.$; Fig. 3).

\section{DISCUSSION}

Several studies about the trophic ecology of Sphyrna lewini report that this species feeds on cephalopods, fishes, rays, and crustaceans (Torres-Rojas et al. 2006, EstupiñánMontaño et al. 2009, Torres-Rojas et al. 2010, Zanella et al. 2010, Galván-Magaña et al. 2013, Torres-Rojas et al. 2015). This species is considered as an important consumer of cephalopods in the eastern Pacific (Estupiñán-Montaño et al. 2009, Galván-Magaña et al. 2013) and feeds mainly in oceanic zones (Loor-Andrade et al. 2015).

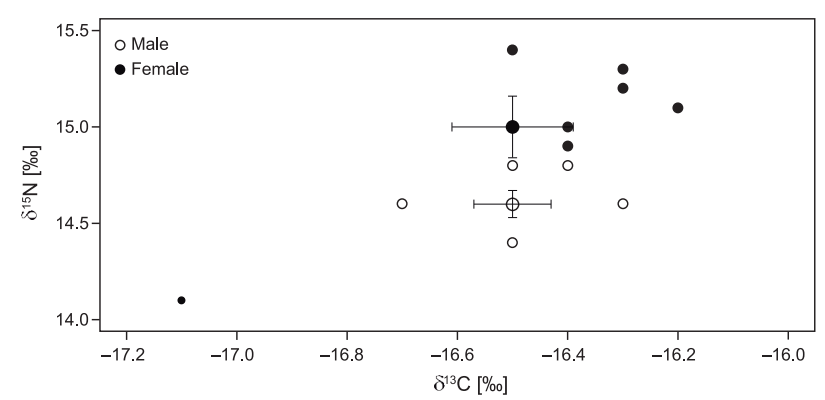

Fig. 4. Isotopic values of $\delta^{13} \mathrm{C}$ and $\delta^{15} \mathrm{~N}($ mean $\pm \mathrm{SE}$ ) by sex in Carcharhinus falciformis at Malpelo Island, Colombia

Table 1

$\delta^{13} \mathrm{C}$ and $\delta^{15} \mathrm{~N}$ values, isotopic range and $\mathrm{C} \div \mathrm{N}$ ratio of Sphyrna lewini and Carcharhinus falciformis samples, with (bulk) and without (lipid-free) lipid and urea extraction

\begin{tabular}{|c|c|c|c|c|c|c|c|c|c|}
\hline \multirow{2}{*}{ Species } & \multirow{2}{*}{ Variable } & \multirow{2}{*}{ Lipid-free [\%o] } & \multirow{2}{*}{ Bulk [\%o] } & \multicolumn{2}{|c|}{ Difference [\%o] } & \multirow{2}{*}{ Statistic } & \multirow{2}{*}{$\begin{array}{l}95 \% \mathrm{IC} \\
\text { (lower) }\end{array}$} & \multirow{2}{*}{$\begin{array}{l}95 \% \mathrm{IC} \\
\text { (upper) }\end{array}$} & \multirow{2}{*}{$P$} \\
\hline & & & & Range & Mean \pm SE & & & & \\
\hline \multirow[t]{3}{*}{ S. lewini } & $\delta^{13} \mathrm{C}$ & $-16.0 \pm 0.13$ & $-16.3 \pm 0.12$ & -0.05 to 0.78 & $0.26 \pm 0.07$ & $W=55$ & -0.699 & 0.100 & 0.135 \\
\hline & $\delta^{15} \mathrm{~N}$ & $15.9 \pm 0.11$ & $15.5 \pm 0.12$ & -0.41 to 0.83 & $0.43 \pm 0.09$ & $W=32.5$ & -0.800 & 0.100 & 0.008 \\
\hline & $\mathrm{C} \div \mathrm{N}$ & $3.09 \pm 0.02$ & $2.91 \pm 0.03$ & 0 to 0.33 & $0.18 \pm 0.03$ & $W=157$ & 0.100 & 0.200 & $<0.05$ \\
\hline \multirow[t]{3}{*}{ C. falciformis } & $\delta^{13} \mathrm{C}$ & $-16.3 \pm 0.06$ & $-16.5 \pm 0.07$ & -0.07 to 0.46 & $0.19 \pm 0.05$ & $W=34$ & -0.3 & -0.00003 & 0.028 \\
\hline & $\delta^{15} \mathrm{~N}$ & $15.3 \pm 0.09$ & $14.9 \pm 0.11$ & -0.09 to 0.86 & $0.46 \pm 0.09$ & $t=-3.29$ & -0.716 & -0.117 & 0.002 \\
\hline & $\mathrm{C} \div \mathrm{N}$ & $3.05 \pm 0.01$ & $2.89 \pm 0.02$ & 0 to 0.25 & $0.15 \pm 0.02$ & $W=128$ & 0.099 & 0.200 & 0.002 \\
\hline
\end{tabular}

Values are mean \pm standard error of the mean (SE).

Table 2

$\delta^{13} \mathrm{C}$ and $\delta^{15} \mathrm{~N}$ values, isotopes range and estimated trophic position (TP) of Sphyrna lewini and Carcharhinus falciformis at Malpelo Island, Colombia

\begin{tabular}{|c|c|c|c|c|c|c|}
\hline \multirow{2}{*}{ Species } & \multirow{2}{*}{ Sex } & \multirow{2}{*}{$n$} & \multicolumn{2}{|c|}{$\delta^{13} \mathrm{C}[\% 0]$} & \multicolumn{2}{|c|}{$\delta^{15} \mathrm{~N}[\% 0]$} \\
\hline & & & Range & Mean \pm SE & Range & Mean \pm SE \\
\hline S. lewini & ND & 14 & -16.9 to -15.5 & $-16.0 \pm 0.13$ & 14.9 to 16.4 & $15.9 \pm 0.11$ \\
\hline \multirow[t]{3}{*}{ C. falciformis } & Both & 12 & -17.1 to -16.2 & $-16.3 \pm 0.06$ & 14.1 to 15.4 & $15.3 \pm 0.09$ \\
\hline & Males & 5 & -16.7 to -16.3 & $-16.5 \pm 0.07$ & 14.4 to 14.8 & $14.7 \pm 0.07$ \\
\hline & Females & 7 & -17.1 to -16.2 & $-16.5 \pm 0.11$ & 14.9 to 15.4 & $15.0 \pm 0.16$ \\
\hline
\end{tabular}

$\mathrm{ND}=$ not determined, $\mathrm{SE}=$ standard error of the mean. 
Table 3

Trophic position estimated for Sphyrna lewini and Carcharhinus falciformis, based on important prey species (mixing model and stomach contents studies)

\begin{tabular}{|c|c|c|c|c|c|c|c|c|c|}
\hline \multirow{3}{*}{ Prey species } & \multirow{3}{*}{$\begin{array}{l}\text { Higher taxon } \\
\text { (class) }\end{array}$} & \multicolumn{4}{|c|}{ Sphyrna lewini } & \multicolumn{4}{|c|}{ Carcharhinus falciformis } \\
\hline & & \multicolumn{2}{|c|}{ Contribution [\%] } & \multicolumn{2}{|c|}{ Trophic position } & \multicolumn{2}{|c|}{ Contribution [\%] } & \multicolumn{2}{|c|}{ Trophic position } \\
\hline & & Mean & Range & Range & Mean \pm SE & Mean & Range & Range & Mean $\pm \mathrm{SE}$ \\
\hline Dosidicus gigas & $\mathrm{da}$ & 21.0 & $0.0-42.0$ & $4.66-5.85$ & $5.55 \pm 0.04$ & 19.0 & 0.0 & $5.36-5.81$ & $5.65 \pm 0.04$ \\
\hline Ommastrephes bartramii & Cephalopoda & 26.0 & $0.0-51.0$ & $3.83-5.94$ & $5.65=$ & 22.0 & $0.1-42.0$ & $5.31-5.65$ & $5.51 \pm 0.03$ \\
\hline $\begin{array}{l}\text { Lolliguncula (Loliolopsis) } \\
\text { diomedeae }\end{array}$ & Cephalopoda & 0.6 & $0.0-18.0$ & $4.66-4.84$ & $4.77 \pm$ & 0.9 & $0.0-22.0$ & - & - \\
\hline Larimus argenteus & Actinopterygii & 0.7 & $0.0-21.0$ & $3.83-4.01$ & $3.95 \pm 0.04$ & 10.0 & $0.0-24.0$ & - & - \\
\hline $\begin{array}{l}\text { Sthenoteuthis } \\
\text { oualaniensis }\end{array}$ & Cephalopoda & 20.0 & $0.0-39.0$ & - & - & 19.0 & $0.0-36.0$ & $5.10-5.43$ & $5.29 \pm 0.03$ \\
\hline Auxis thazard & Actinof & 0.9 & $0.0-24.0$ & - & - & 11.0 & $0.0-25.0$ & - & - \\
\hline Anchoa spp. & Actinopterygii & 0.9 & $0.0-24.0$ & - & - & 10.0 & $0.0-25.0$ & - & - \\
\hline Overall & & - & - & $3.83-5.94$ & $5.25 \pm 0.12$ & - & - & $5.10-5.81$ & $5.48 \pm 0.18$ \\
\hline
\end{tabular}

$\mathrm{SE}=$ standard error of the mean.

The $\delta^{13} \mathrm{C}$ values obtained in this study for Sphyrna lewini $(-16.3 \pm 0.1 \%)$ agree with those obtained by Loor-Andrade et al. (2015) $(-15.9 \pm 0.4 \%$ ), who reported depleted values of $\delta^{13} \mathrm{C}$ for this species. These values are characteristic of the oceanic zone (Niño-Torres et al. 2006, Páez-Rosas et al. 2014), because coastal food webs are generally enriched in ${ }^{13} \mathrm{C}$ compared with those offshore due to the influence of benthic primary production (France 1995, Tanaka et al. 2008) or upwelling (Burton and Koch 1999, Graham et al. 2010). The similarity of the results may be due to: (1) the high mobility of $S$. lewini throughout the ETP (Bessudo et al. 2011b); (2) the metabolic turnover rate of muscle tissue, between 345 and 555 days (MacNeil et al. 2005, Logan and Lutcavage 2010); and (3) the consumption of several cephalopod species in neritic and oceanic areas (epipelagic and mesopelagic zones; Estupiñán-Montaño et al. 2009, Galván-Magaña et al. 2013).

The results of this study support the hypothesis of Bessudo et al. (2011a, 2011b), who suggest that during the night, Sphyrna lewini leaves Malpelo Island, probably to feed. The negative values of $\delta^{13} \mathrm{C}$ observed in this study for S. lewini tissues (Tables 1 and 2) are characteristic of oceanic zones (Niño-Torres et al. 2006, Páez-Rosas et al. 2014), where $S$. lewini would consume epipelagic and mesopelagic cephalopods (e.g., Dosidicus gigas, Histioteuthis spp., Mastigoteuthis spp., and Sthenoteuthis oualaniensis) (Estupiñán-Montaño et al. 2009, Galván-Magaña et al. 2013). Furthermore, the wide isotopic niche suggests that $S$. lewini feeds in both coastal and oceanic environments, or that there are individual differences in diet.

The silky shark, Carcharhinus falciformis, feeds mainly on teleosts but also on cephalopods and crustaceans (Cabrera-Chávez et al. 2010, Duffy et al. 2015, EstupiñánMontaño et al. 2017) and, occasionally, on sea turtles (Estupiñán-Montaño et al. 2017, Acevedo unpublished*). This species is considered to be a selective predator in the ETP, with a preference for the scombrid genus Thunnus (see Duffy et al. 2015, Estupiñán-Montaño et al. 2017), which normally inhabits oceanic zones and forms schools near seamounts. Previous results are in line with those of the present study, as the depleted ${ }^{13} \mathrm{C}$ values obtained here (Tables 1 and 2) are typical of oceanic areas. The narrow isotopic niche observed in this study suggests that $C$. falciformis has a reduced habitat use, with narrow depth (0 to $85 \mathrm{~m})$ (Kohin et al. 2006, Filmalter et al. 2010) and temperature range $\left(26\right.$ to $\left.30^{\circ} \mathrm{C}\right)$ (Kohin et al. 2006).

The enriched values of $\delta^{15} \mathrm{~N}$ in its muscle tissue suggest that Sphyrna lewini spans primary to tertiary consumer roles (TP Range: 3.4-6.6) (Hussey et al. 2015) (Table 3), and that Carcharhinus falciformis has a tertiary consumer role (Hussey et al. 2015) (Table 3), occupying high trophic levels in the marine ecosystem of Malpelo Island and the ETP. These results agree with other studies that have estimated a high trophic position for sharks (Cortés 1999, Bornatowski et al. 2014, Li et al. 2014, Hussey et al. 2015, Estupiñán-Montaño et al. 2017).

Our results suggest that Sphyrna lewini and Carcharhinus falciformis co-occur around of Malpelo Island, with resource partitioning, similar to other reports for sympatric species (Bethea et al. 2004, Papastamatiou et al. 2006, Vaudo and Heithaus 2011). Our results further support the theoretical prediction that the diets of cooccurring species of sharks differ and that sharks with very similar diets do not co-occur (Papastamatiou et al. 2006).

These sympatric sharks co-occur in Malpelo Island, but they do not share their isotopic niche in a significant way. This result may be caused by: (1) the trophic specialization of both species, which reduces interspecific competition; or (2) different habitat use, with Sphyrna lewini showing greater horizontal and vertical movements (Bessudo et al. 2011a, 2011b), and Carcharhinus falciformis being more limited in its movements by its physiological characteristics, which restrict it to narrower niches (Kohin et al. 2006, Filmalter et al. 2010).

\footnotetext{
* Acevedo G. 1996. Contribución al estudio de la biología y la dinámica poblacional de los tiburones de la familia Carcharhinidae (Chondricthyes: Lamniformes) en la Ensenada de Panamá. Thesis. Facultad de Ciencias, Universidad del Valle, Cali, Colombia.
} 
In conclusion, this study suggests that Sphyrna lewini and Carcharhinus falciformis do not feed around Malpelo Island, but they may use Malpelo Island as a resting and cleaning area (Klimley and Nelson 1984, Klimley et al. 1993). There is a need for more research to increase biological and ecological knowledge of both species, which will allow us to understand their role, particularly within marine protected areas throughout the Eastern Pacific Ocean. This study contributes to the knowledge of the trophic ecology of $S$. lewini and $C$. falciformis in the largest marine protected area of the Colombian Pacific, the Malpelo Fauna and Flora Sanctuary (Malpelo FFS), and the Eastern Tropical Pacific (ETP). This information helps to understand the role of the two most abundant shark species at Malpelo Island. Our results will help to develop management and conservation plans for these sympatric species in this marine protected area.

\section{ACKNOWLEDGEMENT}

We thank the Parques Nacionales Naturales de Colombia, Fundación Malpelo y Otros Ecosistemas Marinos and all the 2013 team at Malpelo FFS for their support in collecting the samples. We would also like to thank the CICIMAR-IPN and the University of Los Andes (Bogotá) for allowing us to analyse the samples in their facilities. We thank Isabelle Gamache and Nicole Ward for editing the English text.

We acknowledge the Fundación Alium Pacific for support granted to C. Estupiñán-Montaño. Secretaría de Investigación y Posgrado del IPN(SIP-IPN) kindly provided Grant SIP20150355 and Grant SIP20164779 to A. SánchezGonzález. The Comisión de Operación y Fomento de Actividades Académicas (COFAA) and the Estímulo al Desempeño de los Investigadores (EDI) provided financial assistance to F. Galván-Magaña.

\section{REFERENCES}

Baum J., Clarke S., Domingo A., Ducrocq M., Lamónaca A.F., Gaibor N., Graham R., Jorgensen S., Kotas J.E., Medina E., Martinez-Ortiz J., Monzini Taccone di Sitizano J., Morales M.R., Navarro S.S., Pérez-Jiménez J.C., Smith W., Valenti S.V., Vooren, C.M. 2007. Sphyrna lewini. The IUCN Red List of Threatened Species 2007: e.T39385A10190088. DOI: 10.2305/IUCN.UK.2007.RLTS.T39385A10190088.en

Baum J.K., Kehler D.G., Myers R.A. 2005. Robust estimates of decline for pelagic shark population in the northwest Atlantic and Gulf of Mexico. Fisheries 30 (10): 26-28.

Baum J.K., Myers R.A., Kehler D.G., Worm B., Harley S.J., Doherty P.A. 2003. Collapse and conservation of shark populations in the northwest Atlantic. Science 299 (5605): 389-392.

DOI: $10.1126 /$ science. 1079777

Bessudo S., Soler G.A., Klimley A.P., Ketchum J.T., Arauz R., Hearn A., Guzmán A., Calmettes B. 2011a. Vertical and horizontal movements of the scalloped hammerhead shark (Sphyrna lewini) around Malpelo and Cocos Islands (Tropical Eastern Pacific) using satellite telemetry. Boletín de Investigaciones Marinas y Costeras 40 (Supl. 1): 91-106.

Bessudo S., Soler G.A., Klimley A.P., Ketchum J.T., Hearn A., Arauz R. 2011b. Residency of the scalloped hammerhead shark (Sphyrna lewini) at Malpelo Island and evidence of migration to other islands in the Eastern Tropical Pacific. Environmental Biology of Fishes 91 (2): 165-176.

DOI: $10.1007 / \mathrm{s} 10641-011-9769-3$

Bethea D.M., Buckel J.A., Carlson J.K. 2004. Foraging ecology of the early life stages of four sympatric shark species. Marine Ecology Progress Series 268: 245-264. DOI: $10.3354 /$ meps 268245

Bornatowski H., Braga R.R., Abilhoa V., Corrêa M.F.M. 2014. Feeding ecology and trophic comparisons of six shark species in a coastal ecosystem off southern Brazil. Journal of Fish Biology 85 (2): 246-263.

DOI: $10.1111 / \mathrm{jfb} .12417$

Burton R.K., Koch P.L. 1999. Isotopic tracking of foraging and long-distance migration in northeastern Pacific pinnipeds. Oecologia 119 (4): 578-585. DOI: $10.1007 / \mathrm{s} 004420050822$

Cabrera-Chávez-Costa A.A., Galván-Magaña F., Escobar-Sánchez O. 2010. Food habits of the silky shark Carcharhinus falciformis (Müller \& Henle, 1839) off the western coast of Baja California Sur, México. Journal of Applied Ichthyology 26 (4): 499-503. DOI: $10.1111 /$ j.1439-0426.2010.01482.x

Compagno L.J.V. 1984. FAO species catalogue. Vol. 4. Sharks of the world: An annotated and illustrated guide of shark species known to date. Part 2. Carcharhiniformes. FAO Fisheries Synopsis No. 125, FAO, Rome.

Cortés E. 1999. Standardized diet composition and trophic levels of sharks. ICES Journal of Marine Science $\mathbf{5 6}$ (5): 707-171.

DOI: $10.1006 /$ jmsc. 1999.0489

Duffy L.M., Olson R.J., Lennert-Cody C.E., GalvánMagaña F., Bocanegra-Castillo N., Kuhnert P.M. 2015. Foraging ecology of the silky shark, Carcharhinus falciformis, captured by the tuna purseseine fishery in the eastern Pacific Ocean. Marine Biology 162 (3): 571-593. DOI: $10.1007 / \mathrm{s} 00227-014-2606-4$

Dulvy N.K., Baum J.K., Clarke S., Compagno L.J.V., Cortés E., Domingo A., Fordham S., Fowler S., Francis M.P., Gibson C., Martínez J., Musick J.A., Soldo A., Stevens J.D., Valenti S. 2008. You can swim but you can't hide: The global status and conservation of oceanic pelagic sharks and rays. Aquatic Conservation Marine and Freshwater Ecosystems 18 (5): 459-482. DOI: $10.1002 /$ aqc. 975

Estupiñán-Montaño C., Cedeño-Figueroa L.G., Galván-Magaña F. 2009. Hábitos alimentarios del tiburón martillo Sphyrna lewini (Griffith \& Smith, 1834) (Chondrichthyes) en el Pacífico ecuatoriano. Feeding habits of the scalloped hammerhead shark Sphyrna lewini (Griffith \& Smith, 1834) (Chondrichthyes) in 
the Ecuadorian Pacific. Revista de Biología Marina y Oceanografía 44 (2): 379-386. [In Spanish and English.] DOI: 10.4067/S0718-19572009000200011

Estupiñán-Montaño C., Pacheco-Triviño F., CedeñoFigueroa L.G., Galván-Magaña F., EstupiñánOrtíz J.F. 2017. Diet of three sharks in the Ecuadorian Pacific, Carcharhinus falciformis, Carcharhinus limbatus, and Nasolamia velox. Journal of the Marine Biological Association of the United Kingdom.

DOI: 10.1017/S002531541600179X

Filmalter J.D., Dagorn L., Cowley P.D., Taquet M. 2010. First descriptions of the behavior of silky sharks, Carcharhinus falciformis, around drifting fish aggregating devices in the Indian Ocean. Bulletin of Marine Science 87 (3): 325-337.

DOI: $10.5343 / \mathrm{bms} .2010 .1057$

Fischer W., Krupp F., Schneider W., Sommer C., Carpenter K.E., Niem V.H. 1995. Guía FAO para la identificación de especies para los fines de la pesca. Pacífico Centro-Oriental. Vol. 2. Vertebrados, Parte 1. Pp. 647-743. FAO, Rome.

France R.L. 1995. Carbon-13 enrichment in benthic compared to planktonic algae: Foodweb implications. Marine Ecology Progress Series 124 (1-3): 307-313. DOI: $10.3354 /$ meps 124307

Galván-Magaña F., Polo-Silva C., Hernández-Aguilar S.B., Sandoval-Londoño A., Ochoa-Díaz M.R., Aguilar-Castro N., Castañeda-Suárez D., ChávezCosta A.C., Baigorrí-Santacruz Á., Torres-Rojas Y.E., Abitia-Cárdenas A. 2013. Shark predation on cephalopods in the Mexican and Ecuadorian Pacific Ocean. Deep-Sea Research Part II: Topical Studies in Oceanography 95: 52-62.

DOI: $10.1016 /$ j.dsr2.2013.04.002

Graham B.S., Koch P.L., Newsome S.D., McMahon K.W., Aurioles D. 2010. Using isoscapes to trace the movements and foraging behaviour of top predators in oceanic ecosystems. Pp. 299-318.

DOI: 10.1007/978-90-481-3354-3_14 In: West J.B., Bowen G.J., Dawson T.E., Tu K.P. (eds.) Isoscapes: Understanding movement, pattern, and process on Earth through isotope mapping. Springer, Dordrecht, the Netherlands.

DOI: $10.1007 / 978-90-481-3354-3$

Heithaus M.R., Frid A., Wirsing A.J., Worm B. 2008. Predicting ecological consequences of marine top predator declines. Trends in Ecology and Evolution 23 (4): 202-210.

DOI: $10.1016 /$ j.tree.2008.01.003

Hussey N.E., MacNeil M.A., Olin J.A., McMeans B.C., Kinney M.J., Chapman D.D., Fisk A.T. 2012. Stable isotopes and elasmobranchs: Tissue types, methods, applications and assumptions. Journal of Fish Biology 80 (5): 1449-1484.

DOI: $10.1111 / \mathrm{j} .1095-8649.2012 .03251 . \mathrm{x}$

Hussey N.E., MacNeil M.A., Siple M.C., Popp B.N., Dudley S.F.J., Fisk A.T. 2015. Expanded trophic complexity among large sharks. Food Webs 4: 1-7. DOI: 10.1016/j.fooweb.2015.04.002
Jackson A.L., Inger R., Parnell A.C., Bearhop S. 2011. Comparing isotopic niche widths among and within communities: SIBER-Stable Isotope Bayesian Ellipses in R. Journal of Animal Ecology 80 (3): 595602.

DOI: $10.1111 /$ j.1365-2656.2011.01806.x

Kim S.L., Koch P.L. 2012. Methods to collect, preserve, and prepare elasmobranch tissues for stable isotope analysis. Environmental Biology of Fishes 95 (1): 53-63.

DOI: $10.1007 / \mathrm{s} 10641-011-9860-9$

Kim S.L., Tinker M.T., Estes J.A., Koch P.L. 2012. Ontogenetic and among-individual variation in foraging strategies of northeast Pacific white sharks based on stable isotope analysis. PloS ONE 7 (9): e45068.

DOI: 10.1371/journal.pone.0045068

Klimley A.P. 1981. Grouping behaviour in the scalloped hammerhead shark. Oceanus 14: 65-71.

Klimley A.P., Cabrera-Mancilla I., Castillo-Geniz J.L. 1993. Descripción de los movimientos horizontales y verticales del tiburón martillo Sphyrna lewini, del sur del Golfo de California, México. Horizontal and vertical movements of the scalloped hammerhead shark, Sphyrna lewini, in the southeastern Gulf of California, Mexico. Ciencias Marinas 19 (1): 95-115. [In Spanish and English.]

Klimley A.P., Nelson D.R. 1981. Schooling of the scalloped hammerhead shark, Sphyrna lewini, in the Gulf of California. Fishery Bulletin 79 (2): 356-360.

Klimley A.P., Nelson D.R. 1984. Diel movement patterns of the scalloped hammerhead shark (Sphyrna lewini) in relation to El Bajo Espiritu Santo: A refuging central-position social system. Behavioral Ecology and Sociobiology 15 (1): 45-54.

DOI: $10.1007 / \mathrm{BF} 00310214$

Kohin S., Arauz R., Holts D., Vetter R. 2006. Preliminary results: Behavior and habitat preferences of silky shark (Carcharhinus falciformis) and big eye thresher shark (Alopias superciliosus) tagged in the Eastern Tropical Pacific. Pp. 1-3.In: Rojas M., Zanella I., (eds.) Memoria 1er Seminario-Taller del Estado del Conocimiento de la Condrictiofauna de Costa Rica. 2 de Febrero 2006, Santo Domingo de Heredia, Costa Rica. Instituto Nacional de Biodiversidad INBIO, Costa Rica. http:// www.pretoma.org/wp-content/uploads/2008/07/ marcaje-satelital.pdf

Li Y., Gong Y., Chen X., Dai X., Zhu J. 2014. Trophic ecology of sharks on the mid-east Pacific Ocean inferred from stable isotopes. Journal of Ocean University of China 13 (2): 278-282. DOI: $10.1007 / \mathrm{s} 11802-014-2071-1$

Logan H.M., Lutcavage M.E. 2010. Stable isotope dynamics in elasmobranch fishes. Hydrobiologia 644 (1): 231-244.

DOI: $10.1007 /$ s10750-010-0120-3

Loor-Andrade P., Galván-Magaña F., ElorriagaVerplancken F.R., Polo-Silva C., Delgado-Huertas A. 2015. Population and individual foraging patterns 
of two hammerhead sharks using carbon and nitrogen stable isotopes. Rapid Communications in Mass Spectrometry 29 (9): 821-829.

DOI: $10.1002 / \mathrm{rcm} .7169$

MacNeil M.A., Skomal G.B., Fisk A.T. 2005. Stable isotopes from multiple tissues reveal diet switching in sharks. Marine Ecology Progress Series 302: 199-206. DOI: 10.3354/meps302199

Niño-Torres C.A., Gallo-Reynoso J.A., GalvánMagaña F., Escobar-Briones E., Macko S.A. 2006. Isotopic analysis of $\delta^{13} \mathrm{C}, \delta^{15} \mathrm{~N}$, and $\delta^{34} \mathrm{~S}$ "a feeding tale" in teeth of the longbeaked common dolphin, Delphinus capensis. Marine Mammal Science 22 (4): 831-846.

DOI: $10.1111 / \mathrm{j} .1748-7692.2006 .00065 . \mathrm{x}$

Papastamatiou Y.P., Wetherbee B.M., Lowe C.G., Crow G.L. 2006. Distribution and diet of four species of carcharhinid shark in the Hawaiian Islands: Evidence for resource partitioning and competitive exclusion. Marine Ecology Progress Series 320: 239-251. DOI: $10.3354 /$ meps 320239

Páez-Rosas D., Aurioles-Gamboa D., Alava J.J., Palacios D.M. 2012. Stable isotopes indicate differing foraging strategies in two sympatric otariids of the Galapagos Islands. Journal of Experimental Marine Biology and Ecology 424-425: 44-52.

DOI: 10.1016/j.jembe.2012.05.001

Páez-Rosas D., Riofrío-Lazo M., Aurioles-Gamboa D. 2014. Flexibility in the foraging strategies of the Galapagos sea lion inferred from a multiple approach analysis. Pp. 71-80.

DOI: 10.1007/978-3-319-02769-2_4 In: Denkinger J., Vinueza L. (eds.) The Galapagos Marine Reserve, Social and Ecological Interactions in the Galapagos Islands. Springer, New York, DOI: 10.1007/978-3319-02769-2

Pauly D., Zeller D. (eds.) 2015. Sea around us concepts, design and data. [Accessed June 2016.] www.searound. org

Parnell A., Jackson A.L. 2013. SIAR: Stable isotopes analysis in R. http://cran.r-project.org/web/packages/ siar/index.html

Parnell A., Phillips D.L., Bearhop S., Semmens B.X., Ward E.J., Moore J.W., Jackson A.L., Grey J., Kelly D.J., Inger R. 2013. Bayesian stable isotopes mixing models. Environmetrics 24 (6): 387-399. DOI: $10.1002 /$ env.2221

Post D.M. 2002. Using stable isotopes to estimate trophic position: Models, methods, and assumptions. Ecology 83 (3): 703-718.

DOI: 10.1890/0012-9658(2002)083[0703:USITET]2.0.CO;2

Post D.M., Layman C.A., Arrington A., Takimoto G., Quattrochi J., Montaña C.G. 2007. Getting to the fact of the matter: Models, methods and assumptions for dealing with lipids in stable isotope analysis. Oecologia 152 (1): 179-189.

DOI: $10.1007 / \mathrm{s} 00442-006-0630-\mathrm{x}$
R Core Team 2014. R: A language and environmental for statistical computing. R Foundation for Statistical Computing, Vienna, Austria. http://www.R-project.org

Rigby C.L., Sherman C.S., Chin A., Simpfendorfer C. 2017. Carcharhinus falciformis. The IUCN Red List of Threatened Species 2017: e.T39370A117721799. 10.2305/IUCN.UK.2017-3. RLTS.T39370A117721799.en

Robertson D.R., Allen G. 2002. Peces costeros del Pacífico Oriental Tropical: Un sistema de información. Instituto Smithsonian de Investigaciones Tropicales. [CD-ROM]. Balboa, Panamá

Shiffman D.S., Gallagher A.J., Boyle M.D., Hammershlag-Peyer C.M., Hammerschlag N. 2012. Stable isotope analysis as a tool for elasmobranch conservation research: A primer for non-specialists. Marine and Freshwater Research 63 (7): 635-643. DOI: $10.1071 / \mathrm{MF} 11235$

Tanaka H., Takasuka A., Aoki I., Ohshimo S. 2008. Geographical variations in the trophic ecology of Japanese anchovy, Engraulis japonicus, inferred from carbon and nitrogen stable isotope ratios. Marine Biology 154 (3): 557-568.

DOI: $10.1007 / \mathrm{s} 00227-008-0949-4$

Torres-Rojas Y.E., Hernández-Herrera A., GalvánMagaña F. 2006. Feeding habits of the scalloped hammerhead, Sphyrna lewini, in Mazatlán waters, southern Gulf of California, Mexico. Cybium 30 (Suppl. to 4): 85-90.

Torres-Rojas Y.E., Hernández-Herrera A., GalvánMagaña F., Alatorre-Ramírez V.G. 2010. Stomach content analysis of juvenile, scalloped hammerhead shark Sphyrna lewini captured off the coast of Mazatlán, Mexico. Aquatic Ecology 44 (1): 301-308. DOI: $10.1007 / \mathrm{s} 10452-009-9245-8$

Torres-Rojas Y.E., Páez Osuna F., Camalich J., Galván Magaña F. 2015. Diet and trophic level of scalloped hammerhead shark (Sphyrna lewini) from the Gulf of California and Gulf of Tehuantepec, Mexico. Iranian Journal of Fisheries Sciences 14 (3): 767-785.

Vaudo J.J., Heithaus M.R. 2011. Dietary niche overlap in a nearshore elasmobranch mesopredator community. Marine Ecology Progress Series 425: 247-260. DOI: $10.3354 /$ meps08988

Wolf N., Carleton S.A., Martínez del Rio C. 2009. Ten years of experimental animal isotopic ecology. Functional Ecology 23 (1): 17-26. DOI: $10.1111 /$ j.1365-2435.2009.01529.x

Zanella I., López A., Arauz R. 2010. La alimentación de tiburones martillo jóvenes (Sphyrna lewini) capturados en el Golfo de Nicoya, Costa Rica. Boletín de Investigaciones Marinas y Costeras 39 (2): 447-453.

Received: 9 February 2017

Accepted: 15 October 2017

Published electronically: 31 December 2017 